\title{
Article
}

\section{Surface and Interface Structure and Tribological Properties of Hydrophilic Polymer Brushes}

\author{
Motoyasu Kobayashi*, Hiroki Yamaguchi*, Yuki TerayAma ${ }^{* *}$, Zhe WANG ${ }^{*}$, \\ Masataka KAIDO $^{* * *}$, Atsushi SUZUKI ${ }^{* * *}$, and Atsushi TAKAHARA ${ }^{* * *, \dagger}$ \\ "Institute for Materials Chemistry and Engineering, Kyushu University, \\ 744 Motooka, Nishi-ku, Fukuoka 819-0395, JAPAN \\ ${ }^{* *}$ Graduate School of Engineering, Kyushu University, 744 Motooka, Nishi-ku, Fukuoka 819-0395, JAPAN \\ ${ }^{* * *}$ TOYOTA Motor Co. 1-Toyota-cho, Toyota, Aichi 472-8572, JAPAN
}

\begin{abstract}
The hydrophilic polymer brushes with $25-35 \mathrm{~nm}$ thick were prepared by surface-initiated atom transfer radical polymerization of (2,2-dimethyl-1,3-dioxolan-4-yl)methyl methacrylate (DMM), 2-methacryloyloxyethyl phosphorylcholine (MPC), 2-dimethylaminoethyl methacrylate (DMAEMA), and vinyl acetate (VAc) on the initiator-immobilized silicon wafer. PDMM, PDMAEMA, and PVAc were converted to poly(2,3-dihyroxypropyl methacrylate) (PDHMA), poly(2methacryloxyethyltrimethylammonium iodide) (PMETA), and poly(vinyl alcohol) (PVA), respectively. Macroscopic frictional properties of the hydrophilic polymer brushes were characterized by sliding a glass ball probe in air, water, and toluene under the load of $0.49 \mathrm{~N}$ at a sliding velocity of $90 \mathrm{~mm} / \mathrm{min}$. The dynamic frictional coefficient of the surfaces immobilized with PDHMA, PMPC, PMETA and PVA brushes were lowered in water (good solvent) compared with in dry air condition, while they increased in toluene (poor solvent). Extremely low friction coefficient of PMPC brush was observed in humid atmosphere because water molecules adsorbed into brush surface acted as a lubricant. Adhesion force measurement of high-density PMPC brush was also carried out by AFM using a colloidal probe. Larger adhesion force was observed in a poor solvent (ethanol/water $=75 / 25, \mathrm{v} / \mathrm{v}$ ) compared with good solvent (pure water), because of strong interaction between a brush and a probe in a poor solvent. These results indicate that the frictional properties largely depend on the solvent quality and the adhesion force between the substrate and the sliding probe.
\end{abstract}

Key Words: Polymer brush / Wettability / Tribology / Friction / Adhesion force

\section{親水性ポリマーブラシの表面・界面構造とトライボロジー特性}

\author{
小林 元康 ${ }^{*}$, 山口 央基 ${ }^{* *}$, 寺山 友規 ${ }^{* *}$, 王 哲 ${ }^{*}$, \\ 海道 昌孝 ${ }^{* * *}$, 鈴木 厚 ${ }^{* * *}$, 高原 淳 ${ }^{* * *, \dagger}$
}

(原稿受理 : 2007年12月 19日)

\begin{abstract}
1. 緒言
ポリマー鎖の一端が共有結合など比較的強固な結合で固 体表面に固定化, 寸なわちグラフトしている場合, 摩擦や洗 浄に対してグラフト鎖が剥離しにくく, 温度変化にも安定 で，表面改質効果を長期にわたって保持することが可能であ ることから, その表面同士の相互作用や摩擦特性も古くから 関心が持たれていた。特に, ポリマーに対して良溶媒中に浸 漬させた状態では，固体表面からグラフト鎖の存在する層に かけては局所的にポリマー濃度が高い状態にあり, そのた
\end{abstract}

\footnotetext{
$\dagger$ Tel: +81-92-802-2517, Fax: +81-92-802-2518, E-mail: takahara@cstf.kyushu-u.ac.jp

* 九州大学先導物質化学研究所

T 819-0395 福岡市西区元岡 744

** 九州大学大学院工学府

₹ 819-0395 福岡市西区元岡 744

*** トヨ夕自動車株式会社

T 472-8572 愛知県豊田市豊田町 1
}

め，グラフト表面同士を接近させたり圧縮させたりすると分 子鎖の排除体積効果により高い浸透圧が発生し，これが垂直 荷重に反発する力となり摩擦抵抗が減少する. ${ }^{1-2)} さ ら に ，$ 対 向するグラフト鎖同土は浸透圧のために相互貫入できない 環境にあり，分子鎖同士の絡み合いも生じにくい. また，ブ ラシ鎖が溶媒和することでブラシ鎖同士の相互作用が小さ くなり，ある程度の垂直荷重領域までは溶媒の流動性が保た れる. そのため, 滑り運動が生じた時にせん断抵抗が小さく, グラフト鎖界面で良好な潤滑が生じる. Kleinらはポリスチレ ン(PS)をグラフトしたマイカ表面について表面間力測定装置 を用いてこの摩擦機構を検証し，トルエン中低荷重条件下で はPSグラフト表面は低摩擦を示すことを確認している。一 方, 高荷重条件はPSグラフト層が押しつぶされ局所的に濃度 が高くなり，粘度が上昇するとともにせん断力も増大するた め高い摩擦係数が観測されたと述べている. ${ }^{3-5)}$ また, 電解質 ポリマーをグラフトしたマイカ表面では, 静電反発作用によ 
りブラシ表面間の相互作用が低減するためグラフト化密度 に関係なく極めて低い動摩擦係数 $(0.0006 \sim 0.001)$ を示すこと を報告している.) ポリエチレンオキシド(PEO)ブラシの場合, グラフト密度が $0.01 \sim 0.05$ 本 $/ \mathrm{nm}^{2}$ 程度, すなわち準希薄ブラシ 領域ではグラフト密度とともに動摩擦係数が上昇すること が観測されている.7)これはグラフト密度が低いためにブラシ 鎖間に他方のブラシ鎖が貫入するだけの空間があり, 分子鎖 同士がからみあうなどの効果が働き摩擦係数が増大したた めと説明されている.

ポリマーを固体表面にグラフトする方法には，ポリマーの 一部に基板と相互作用する官能基を導入し, これを吸着させ る grafting-to法, および基板表面から直接重合を開始し, ポリ マーを生長させる grafting-from法が知られている. 特に最近は 後者の手法にリビング重合が適用され, 分子量および分子量 分布の制御されたポリマーを基板に固定化できるように なった. リビング重合は開始効率が高く, 重合反応中に生長 種の失活が生じないため, 基板表面から高分子鎖が極めて高 い密度でグラフト化された構造体が得られる.8)これをポリ マーブラシという。高密度であるがゆえに良溶媒中で排除体 積効果によってポリマー鎖は基板平面に対して垂直方向に 伸長した分子形態をとり ${ }^{9)}$ ，ポリマーの分子量に比例してブ ラシ層の厚みが増大する様子が観測される. ${ }^{10)}$ また, 溶媒分子 がブラシ層に浸入すると膨潤するだけでなく高分子濃厚溶 液と同じ状態に達するため高い浸透圧を与え, ブラシ表面の

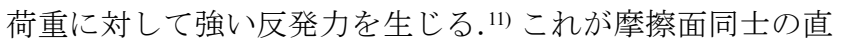
接接触を抑制し，摩擦力を低下させる要因となる.

辻井らは原子移動ラジカル重合(ATRP)法を用いてシリコ ン基板表面から $0.7 \mathrm{chains} / \mathrm{nm}^{2}$ 程度の高密度ポリメタクリル酸 メチル $(\mathrm{PMMA})$ ブラシを調製し, その表面の摩擦力を水平力 顕微鏡(LFM)測定により評価している.12) 具体的にはPMMAブ ラシを付与した直径 $10 \mu \mathrm{m}$ のシリカ粒子を原子間力顕微鏡 (AFM) 用カンチレバーの先端に取り付け，これをプローブと してPMMAブラシ基板表面を走査させた時に生じるカンチ レバーのねじれ量から摩擦力を評価している. その結果, PMMAに対して良溶媒であるトルエン中で観測すると動摩 擦係数は 0.005 以下を示すことが明らかとなった.

このようなナノ〜ミクロスケールの視点に基づくポリ マーブラシの摩擦特性解析の他にも, 工学的応用の観点から 実用環境下におけるマク口な摩擦評価も展開されている. 例 えば，筆者らはシリコン基板上に表面開始ATRP法により高 密度PMMAブラシを調製し, 直径 $10 \mathrm{~mm}$ のステンレス球をプ ローブとして直線摺動型の摩擦試験を試みている. ${ }^{13)}$ トルエ ンなど良溶媒中では摩擦係数の低下が認められ, スピンキャ ス卜膜に比べはるかに耐摩耗性が優れていることを見いだ した. SpencerらはPEOを側鎖に有するポリリジンをシリコン 基板上に吸着させることでPEOブラシ表面を調製すると，水 中で優れた境界潤滑層が形成され，摩擦係数が低下寸ること をPin-on-Disk型摩擦試験機で観測している. ${ }^{14-15)}$ 長田らはポリ (メタクリル酸2-ヒドロキシエチル) ゲル表面にポリスチレン スルホン酸ナトリウム鎖をグラフト化し, ガラスプレート上 におけるすべり摩擦特性を評価している. ${ }^{16)}$ 表面グラフト化 されていないゲルに比べ電解質ポリマーブラシ修飾ゲルは 低摩擦特性を示し, グラフト鎖の分子量が小さいほど（鎖長 が短いほど）摩擦係数は低いことを報告している。

こうした親水性ポリマーブラシによる低摩擦表面の構築
は生体材料開発の観点からも重要である。例えば，生物の関 節が水潤滑を巧みに活用して低摩擦界面を実現しているよ うに，人工関節や生体デバイスを設計する上で親水性表面に よる潤滑機構は関心が持たれている.17-19) 親水性だけでなく高 い生体適合性を目的として分子設計された2-メタクリロイル オキシエチルホスホリルコリン (MPC) $)^{20-21)}$ からなるポリマー ブラシが低摩擦表面を与えることが報告され，人工関節に応 用する試みも行われている. 22

そこで本研究では親水性ポリマーブラシに焦点を当て, 湿 潤条件をはじめ種々の環境下における摩擦特性について検 討を行った. 対象としたのは水酸基を有するポリ（メタクリ ル酸2,3-ジヒドロキシプロピル) (PDHMA)およびポリビニル アルコール(PVA), 双性イオン型電解質のPMPC, カチオン性 電解質のポリ（メタクリイルオキシエチルトリメチルアンモ ニウム塩）(PMETA)である.PDHMAをはじめPVA, PMPC, PMETAはいずれも水溶性ポリマーであるが，それぞれ水素結 合性や極性が異なるため固体表面にグラフトした状態で表 面の濡れ性に差が生じることが予想される．本研究はこれら 一連のブラシ表面の親水性を比較し，水中や湿潤環境下にお ける摩擦特性との関係について検討することを目的とした.

\section{2. 実験}

シリコン基板はピラニア溶液中 $373 \mathrm{~K} に て 1$ 時間洗浄した 後, 真空紫外光 $(\lambda=172 \mathrm{~nm})$ により洗浄したものを用いた. 表 面開始剤となる2-ブロモイソ酪酸（6-トリエトキシシリル） ヘキシル(BHE) も既報 ${ }^{23)}$ に従って合成し, 化学気相吸着法に よりシリコン基板上に固定化した. メタクリル酸2,2-ジメチ ル-1,3,ジオキソラン-4-イルメチル $(\mathrm{DMM})^{23}$ およびMPC ${ }^{24)}$ は 既報に従って合成した. メタクリル酸ジメチルアミノエチ ル(DMAEMA)は市販品（和光）を水素化カルシウム存在下 から蒸留を繰り返し，アセトンで希釈して使用した。臭化 銅 (I) (和光), 塩化銅(I)（和光）, アニソール（東京化成）, アセトン（和光）は常法 ${ }^{25}$ により精製したものを用いた. 䣷酸 ビニル (和光)，2-ブロモイソ酪酸エチル（東京化成）および $N, N, N, N ", N$ "-ペンタメチルジェチレントリアミン（ナカラ イテスク）は水素化カルシウム存在下から蒸留して用いた. ヨウ化メチル（和光）は市販品をそのまま用いた.

Fig. 1 にポリマーブラシの調製法の概略を示す. PDMM $^{23)}$, $\mathrm{PMPC}^{26)}$, ポリ酢酸ビニル $(\mathrm{PVAc})$ ブラシ ${ }^{27)}$ は既報に従って調製 した。特にPDMMおよびPVAcブラシは酸加水分解によりそ れぞれPDHMAとPVAへと変換した。 DMAEMAモノマーは BHE固定化シリコン基板と2-ブロモイソ酪酸エチルを開始剂 として, 塩化銅と $N, N, N$, $N$ ”, $N$ ”-ペンタメチルジエチレント リアミン存在下アセトン中 $303 \mathrm{~K}$ で 12 時間反応させることで 重合した. 得られたPDMAEMAグラフト化基板をメタノール で洗浄した後, ヨウ化メチル/メタノール溶液中室温で数時間 浸漬させることでPMETAブラシへと変換した.この重合反応 で同時に生成するフリーポリマーはポリマーブラシとほぼ 等しい分子量を持つことが知られており, 排除体積クロマト グラフィー $(\mathrm{SEC})$ 測定から数平均分子量 $\left(M_{\mathrm{n}}\right)$ を求め, エリプ ソメトリーにより大気中での膜厚を評価した。また, AFM, X線光電子分光法(XPS), 接触角測定, 赤外吸収分光(IR)測定 によりポリマーブラシの表面特性解析を行った，中性子反射 率(NR)測定によるブラシの固液界面構造解析 ${ }^{26)}$ は高エネル 
ギー加速器研究機構物質構造科学研究所の水平型反射率計 ARISAを用いて行った。

ポリマーブラシ表面の動摩擦係数は直線摺動型新東科学製 Tribostation Type 32を用い13,28), 直径 $10 \mathrm{~mm}$ のガラス球をプロー ブとして室温 $(298 \mathrm{~K}$ )にて垂直荷重 $0.49 \mathrm{~N}$ (応力換算 $139 \mathrm{MPa}$ ), 摺動速度 $90 \mathrm{~mm} / \mathrm{min}$, 振幅 $20 \mathrm{~mm}$ の条件で測定した. 表面凝着 力は原子間力顕微鏡SPA400（SIIナノテクノロジー）に溶液セ ルを取り付けて $298 \mathrm{~K}$ 条件下コロイドプローブ法で測定した. コロイドプローブは直径 $50 \mu \mathrm{m}$ の微小ガラス球を AFM用カン チレバーSI DFM-3 (バネ定数 $0.4 \mathrm{~N} / \mathrm{m}$ ) に光硬化接着剂NOA63 (Norland Pro.製) により接着して作製した.

\section{3. 実験結果と考察}

\section{1 親水性ポリマーブラシ表面の濡れ性と分子鎖形態}

表面開始重合においてモノマーとフリー開始剤（2-ブロモ イソ酪酸エチル）の仕込み比を適切に設定することで, 生成 ポリマーの分子量や膜厚を制御することが可能である. 本実 験では開始剤とモノマーの比を調整することで $M_{\mathrm{n}}$ が約 $10^{4} \sim 10^{5}$ のポリマーブラシがそれぞれ得られ， $M_{\mathrm{n}}$ の上昇ととも に膜厚も直線的に増大寸ることをエリプソメトリーから確 認した. 膜厚と分子量の関係より PDMM と PMPC, PDMAEMA のグラフト化密度は約 $0.36,0.22$, および 0.40 chains $/ \mathrm{nm}^{2}$ と評価 した.これはいずれも高密度ブラシに相当する.ただし, PVAc のグラフト密度は 0.09 chains $/ \mathrm{nm}^{2}$ と低い值となった. PVAcブ ラシはヨウ素移動重合により調製し, 分子量 $M_{\mathrm{n}}=1.8 \times 10^{5}$, 膜 厚 $21 \mathrm{~nm}$ の薄膜が得られたが, この重合はリビング的に進行

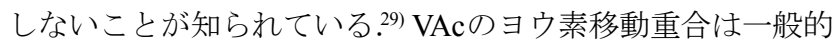
なフリーラジカル重合に比べ比較的分子量分布の狭いポリ マーを与えるが，必ずしも開始効率が定量的ではなく, 停止 反応も完全には抑制できない. そのため, 表面開始ヨウ素移 動重合により得られたPVAcブラシのグラフト密度が低く なった。

各種ポリマーブラシの水およびヨウ化メチレンの接触角 とOwens-Wendt式苟) から求めた表面自由エネルギーを Table I

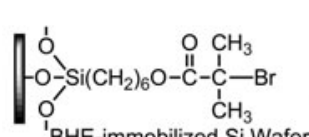
BHE-immobilized Si Wafer<smiles>CCCCCC(C)CC(C)(C)C(C)(C)CC(C)C</smiles>
PDMM Brush Ò

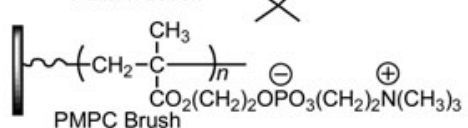

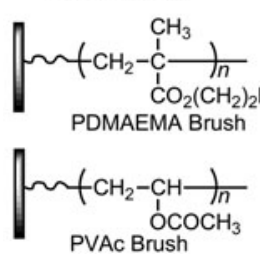

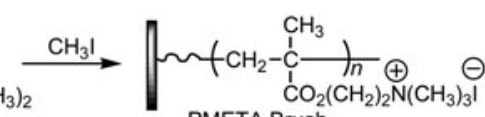
META Brush

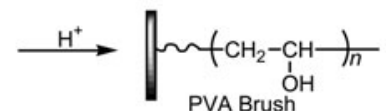

Fig. 1. Preparation of hydrophilic polymer brushes by surface-initiated polymerization.
に示した.PDMMとPVAc以外のポリマーは水溶性である.た だし，それぞれ水との親和性が異なるため接触角も異なる值 を示している. これは水和状態の違いを反映している. 水酸 基を有するPDHMA やPVAの場合は水素結合の形成により水 和が生じるのに対し，イオン性の極性基を有するPMPCや PMETA では水分子の電荷との静電相互作用により水和する. また，ノニオン性PDHMAやPVAブラシは前進接触角と後退 接触角の差が大きい. このヒステリシスは最表面の構造変化 に起因している，空気界面では表面自由エネルギーを低くす るために水酸基がブラシ薄膜内部へ埋没した構造をしてい るが，水界面では水酸基が最表面に露出した構造へと変化す るため後退接触角が低下寸る。一方，イオン性ポリマーブラ シでは接触角が低く前進および後退接触角の差も小さい. 特 にPMPCは水滴が接触したと同時に液滴が濡れ広がり，接触 角は測定できないほど0度に近い. ${ }^{26)}$ 逆に水中では気泡との接 触角がほぼ180度を示し，気泡が表面にとどまることがない。 PMPCの水和構造は特殊であり，親水性にもかかわらず結合 水を持たないことが分光学的に明らかにされている. ${ }^{31)}$ その ため, PMPCブラシ表面では水分子が束縛されずバルク水と 同様な交換速度を維持でき，水が濡れ広がりやすいと考えら れる. また，水中におけるポリマー分子鎖のコンホメーション を確認するため, ブラシ／重水界面におけるNR測定を行っ た. 例えばPMPCの場合, 大気中では膜厚 $25 \mathrm{~nm}$ のブラシが重 水界面においては膨潤し，基板表面から約 $60 \mathrm{~nm}$ まで伸長し

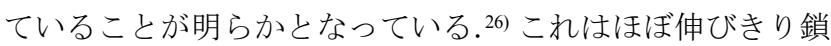
長に匹敵することから，ブラシ内部では極めて高い浸透圧が 発生しブラシ鎖がほぼ垂直方向に伸長していると考えられ る. ところで, PMPCは水にもエタノールにも可溶であるが, その混合溶液 $\left(\mathrm{EtOH} / \mathrm{H}_{2} \mathrm{O}=7 / 3, \mathrm{v} / \mathrm{v}\right)$ には不溶となる性質を有し ている. ${ }^{32-33)} こ の$ cononsolvency挙動が観察されるエタノール・ 水混合溶媒中においてPMPCブラシは約 $30 \mathrm{~nm}$ まで収縮して いる様子がNR測定から観測され, ブラシ鎖の形態が溶媒の性 質によって変化することを既報 ${ }^{26)}$ にて報告している.

\section{2 親水性ポリマーブラシ表面の摩擦特性}

摩擦プローブとして直径 $10 \mathrm{~mm}$ のガラス球を用い，垂直荷 重を $50 \mathrm{~g}(0.49 \mathrm{~N})$ として室温 $(298 \mathrm{~K})$ 条件下, 滑り速度 $90 \mathrm{~mm} / \mathrm{min}$ にてポリマーブラシ表面の動摩擦係数を測定した。この条件 下でHertz接触を仮定した接触点における圧力は約139 MPaで あり，ポリマーの降伏強度以上に達する。この場合，摩擦特 性は前述した浸透圧の効果よりもブラシ鎖と摩擦プローブ との相互作用，凝着力が支配的となる。市，マクロな摩擦 試験においてポリマーブラシ表面の摩擦係数は膜厚にある

Table I. Contact angles of polymer brushes immobilized on Si-wafer.

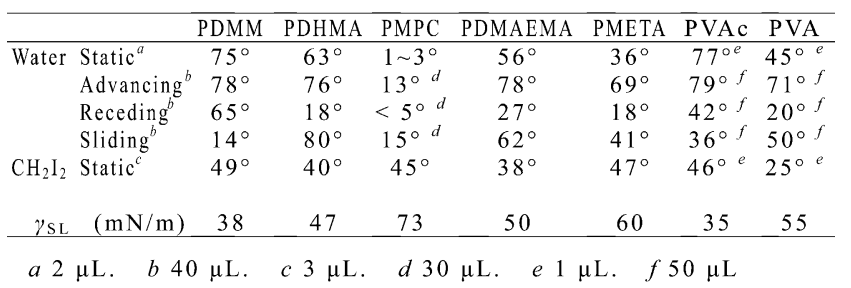




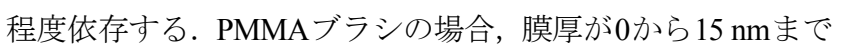
増大するとともに動摩擦係数が低下し，15 nm以上でほぼ一 定值を示した. ${ }^{13)}$ 膜厚が $15 \mathrm{~nm}$ 以下では, 高荷重下においてブ ラシが固定化されているシリコン基板とプローブ球との直 接接触が生じる部分が発生し摩擦係数が高いと考えられる. そのため膜厚の増大とともに直接接触は低減する. また, PDHMAの場合, 膜厚が $0 \sim 15 \mathrm{~nm}$ 以下では膜厚とともに摩擦 係数が増大し, それ以上では一定となった. ${ }^{23)}$ PDHMAブラシ 表面は側鎖に水酸基を有するためPMMAに比べガラス球プ ローブとの凝着力は大きい. また, ガラス球との接触部分で は高い圧縮応力が加わるためにポリマーブラシ鎖末端だけ でなく側鎖や主鎖もガラス球に接触していると予想され，ブ ラシ鎖長が長く（膜厚が大きく）なるにつれてガラス球に接 する官能基数は増え, 凝着力が大きくなるために摩擦係数が 増大したと考えられる.ただし, 接触面積は有限であるため, ある膜厚以上（本研究の場合 $15 \mathrm{~nm}$ 以上）では摩擦係数はほ ぼ一定となったと考えている。本報告で用いた高密度ポリ マーブラシの膜厚はいずれも25 35 nmであり, 以後各種測定 結果を比較するにあたりブラシ膜厚の影響は無視できると 仮定した。

Fig. 2は大気中, 水中, トルエン中におけるシリコン基板お よびPDMM, PDHMAブラシ基板表面の動摩擦係数である. 大 気中に比べ溶媒中では溶媒潤滑の効果のため動摩擦係数は 低下寸るが，さらに溶媒とポリマーとの親和性が動摩擦係数 に大きく反映されている. PDMMは比較的疎水性であるため 貧溶媒である水中よりも良溶媒のトルエン中の方が動摩擦 係数は小さい. また, 親水性のPDHMAの場合, 貧溶媒であ るトルエン中では動摩擦係数が大きいが, 良溶媒の水中では 低下した。つまり, 良溶媒中ではポリマー鎖は溶媒分子との 相互作用が強いが，貧溶媒中では溶媒分子との接触面積を小 さくするために摩擦プローブとの相互作用が相対的に強く なり, 動摩擦係数が増大したと説明できる. また, 大気中に おいてPDHMA ブラシの動摩擦係数は未修飾のシリコン基板 よりも大きい. これはPDHMAの水酸基が水素結合によりガ ラス球と強く相互作用し, せん断応力が大きくなったことが 原因である.

他のポリマーブラシについても同様の周囲媒体依存性が認 められた. Fig. 3は大気中, 水中, トルエン中における PMPC,

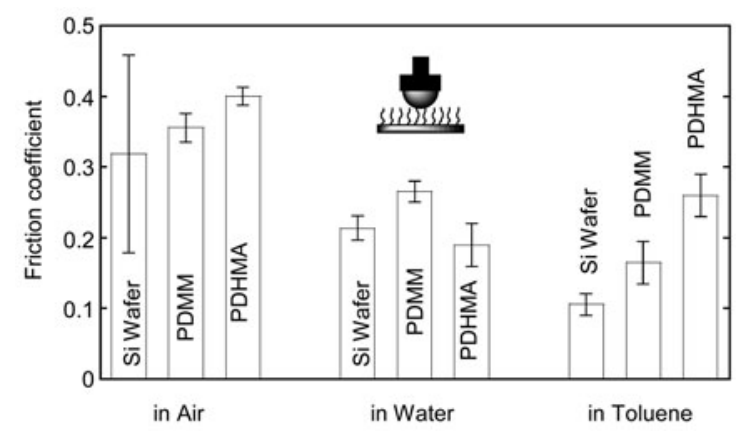

Fig. 2. Friction coefficients of PDMM and PDHMA brushes in air, water, and toluene by sliding a glass ball over a distance of $20 \mathrm{~mm}$ at a sliding velocity of $90 \mathrm{~mm} / \mathrm{min}$ under a load of $0.49 \mathrm{~N}$ at $298 \mathrm{~K}$.
PDMAEMA，PMETAブラシそれぞれの摩擦係数を示してい る. 親水性の高いPMPC, PMETAブラシの場合は水中で最も 低い摩擦係数を示したが, 貧溶媒であるトルエン中では值が 増大した。一方，アルコールから芳香族系有機溶媒まで幅広 い溶媒に対して可溶なPDMAEMAがグラフトされた基板は トルエン中でも比較的低い動摩擦係数を示した. また, Fig. 4 に示したように, 比較的疎水性のPVAcブラシ表面もトルエン 中で低摩擦を示したが，これを加水分解して得られる親水性 のPVAブラシの動摩擦係数は水中で低くトルエン中で上昇し た. 水中での動摩擦係数は水の静的接触角とほぼ対応してお り, $\mathrm{PMPC}<\mathrm{PMETA}<\mathrm{PVA}<\mathrm{PDMAEMA}<\mathrm{PDHMA}$ ブラシ表面の 順に低い。摩擦係数がブラシの親水性に依存していることか ら, 溶媒との親和性により摩擦係数が大きな影響を受けるこ とが明らかである.

また，ガラスプローブ表面にも基板と同じ種類のポリマー ブラシを固定し，ポリマーブラシ同士による摩擦特性評価も 試みた(Fig. 5). 水中における動摩擦係数を基板のみポリマー がグラフトされていた場合と比較するとPDHMA, PMPC, PMETAブラシのいずれも低下していることがわかる.これら 3者の中ではPDHMAが最も高い動摩擦係数を示している. ポ リマー側鎖に存在する 2 つ水酸基が水素結合点となり，ブ ラシ鎖間の相互作用が高いことが原因と考えられる. 双性イ

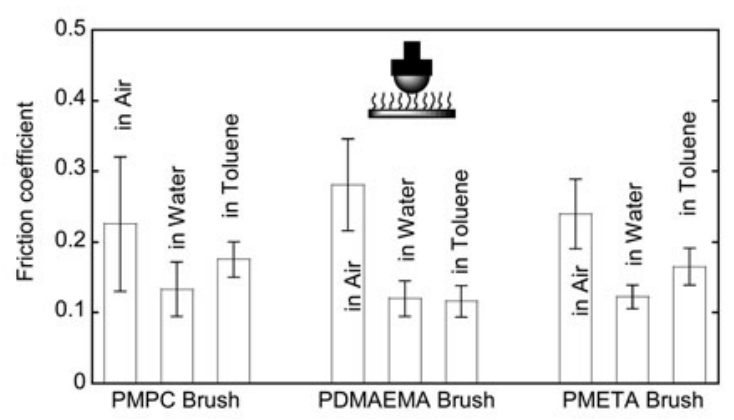

Fig. 3. Friction coefficients of PMPC, PDMAEMA, and PMETA brushes in air, water, and toluene by sliding a glass ball over a distance of $20 \mathrm{~mm}$ at a sliding velocity of $90 \mathrm{~mm} / \mathrm{min}$ under a load of $0.49 \mathrm{~N}$ at $298 \mathrm{~K}$.

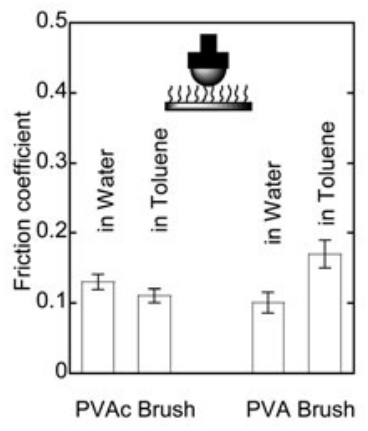

Fig. 4. Friction coefficients of PVAc and PVA brushes in water and toluene by sliding a glass ball over a distance of $20 \mathrm{~mm}$ at a sliding velocity of $90 \mathrm{~mm} / \mathrm{min}$ under a load of $0.49 \mathrm{~N}$ at $298 \mathrm{~K}$. 
オン型高分子電解質のPMPC とカチオン性高分子電解質の PMETA とともに水中での動摩擦係数が約 0.1 を示したが, PMPC は大気中で摩擦試験に大きな湿度依存性が認められ, 特に湿度が $80 \%$ を超えるような高湿潤䨌囲気では動摩擦係 数が 0.05 以下まで低下した。この場合, 親水性および保水性 が極めて高いPMPCブラシ内部に水分子が残存し，基板側プ ローブ側ともに水和ブラシ層が形成されていると思われる. これがシリコン基板とガラス球との直接接触を防ぎ，潤滑膜 として機能していると考えられる.こうした現象はPMETAに は認められず，PMPC特有の性質であった。しかし，これは 同時に湿潤大気中よりも水中での動摩擦係数が大きいとい うことでもある. 現在, その理由を説明できる適切な証拠は そしいが，水中ではブラシ鎖が伸張しており，その一部が摩 擦時に相互貫入することでプローブと基板間の凝着力が増 大し, 動摩擦係数が上昇したと考えられる. また, 流体抵抗 の寄与の可能性も挙げられる.

本測定で得られた動摩擦係数はいずれもKleinらの結果に 比べ一桁以上大きな值である。これは彼らの微視的な測定に 比べマクロな測定では接触面積も荷重も大きいことが原因で あると思われる. 本実験は接触部分においてポリマーブラシ 鎖に $100 \mathrm{MPa}$ オーダーの大きな垂直荷重だけでなく強いせん

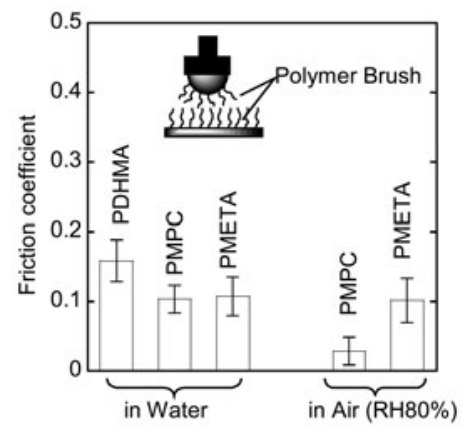

Fig. 5. Friction coefficient of PDHMA, PMPC, and PMETA brushes in water and in humid air by sliding a glass ball immobilized with corresponding hydrophilic polymer brushes over a distance of $20 \mathrm{~mm}$ at a sliding velocity of $90 \mathrm{~mm} / \mathrm{min}$ under a load of $0.49 \mathrm{~N}$ at $298 \mathrm{~K}$.
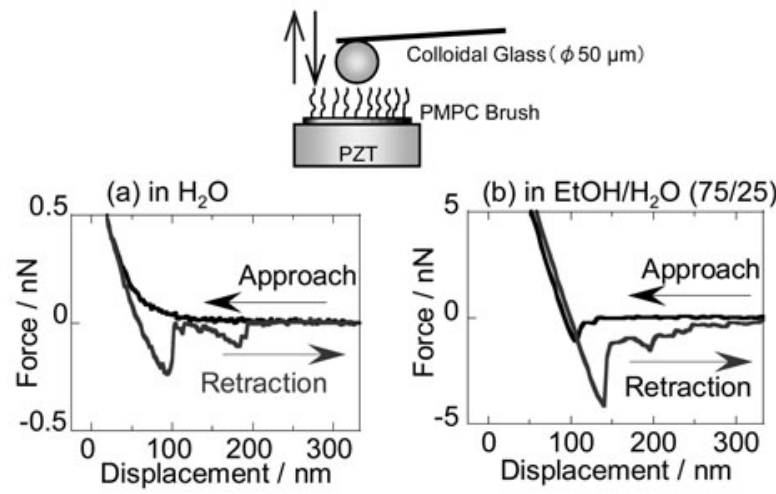

Fig. 6. Adhesion force measurements of high-density PMPC brush in a ethanol/water $(75 / 25, \mathrm{v} / \mathrm{v})$ solution and in pure water at $298 \mathrm{~K}$.
断応力も加わり, かなり過酷な環境で試験を行っている. 従っ て，摩耗の影響も含まれており，今後は摩耗痕の解析ととも に低荷重状態における摩擦特性の評価を行う必要がある.

一般に摩擦力が発生する要因には様々なものがあるが，こ のポリマーブラシ表面の摩擦においては表面凝着力が支配 的のようである。これを確認するためにPMPCブラシ表面の 凝着力をコロイドプローブ法により評価した. Fig. 6は良溶媒 (純水) および貧溶媒中 $\left(\mathrm{EtOH} / \mathrm{H}_{2} \mathrm{O}=75 / 25, \mathrm{v} / \mathrm{v}\right)$ における ForceDistance曲線である. 両者の凝着力值が 10 倍異なることから も明らかなように，貧溶媒中ではかなり大きな凝着力がプ ローブと PMPCブラシ間に働いている．良溶媒である純水中 では，プローブがブラシ表面にアプローチするにつれて徐々 に反発力が検出されるが，貧溶媒中では逆に引力的相互作用 が検出される. また，これらの相互作用が貧溶媒よりも良溶 媒中においてより遠距離にわたって検出されるのは，良溶媒 中でブラシが膨潤し膜厚が増大しているためである。実際, PMPCブラシの膜厚は良溶媒中において乾燥状態の約 2 倍程 度まで増大し，ブラシ鎖が基板表面から 60-70 nmにまで達し ていることがNR測定で確認されている. ${ }^{26)}$ 以上のことから， 貧溶媒中ではブラシ鎖は収縮するとともに摩擦プローブと 強く相互作用するために摩擦係数が増大したのに対し，良溶 媒中では溶媒和により膨潤したブラシ鎖とプローブとの間 に大きな凝着力が生じないために摩擦係数が低下すると説 明できる. 従って, ポリマーブラシ薄膜のトライボロジーに はブラシ表面とプローブとの間に働く凝着力が重要な因子 であることが確認された.

\section{4. 結 論}

表面開始重合により高密度にグラフトされた親水性ポリ マーブラシ薄膜の動摩擦係数は溶媒など周囲媒体とポリ マーとの相溶性および表面凝着力に大きく依存することが 示された，例えば，親水性ポリマーにとって貧溶媒となる溶 液中では摩擦プローブとブラシ表面間の凝着力が大きくな り動摩擦係数も増大寸ることが明らかとなった，一方，水の ような良溶媒中または湿潤条件下ではブラシとプローブ間 の凝着力が低くなり, 摩擦が低下した。 また, 対水接触角の 低い順, すなわち親水性の高い順に水中での動摩擦係数が低 いことも明らかとなった．特に，PMPCブラシ面同士を接触 させた場合， 0.05 程度まで動摩擦係数が低下した。これは， 極めて高い親水性を持つPMPCに大気中の水分子が吸着する ことで水潤滑層が形成されたためと考えられる.

\section{謝 辞}

本研究を行うに当たりPMPCの系につきましては東京大学 大学院工学系研究科マテリアル工学専攻の石原一彦教授よ り的確なアドバイスとご支援を頂きました．また，中性子反 射率測定について高エネルギー加速器研究機構物質構造科 学研究所の鳥飼直也准教授にご協力頂きました。この場を借 りて深く感謝申し上げます. なお, 本研究の一部は九州大学 グローバルCOEプログラム「未来分子システム科学」および 平成19年度科学研究費補助金若手研究B (課題番号19750098) による助成であることを付記し，謝意を表します。 


\section{REFERENCES}

1) Klein J, Ann Rev Mater Sci, 26, 581 (1996).

2) Klein J, Kumacheva E, Perahia D, Fetters LJ, Acta Polym, 49, 617 (1998).

3) Klein J, Kumacheva E, Mahalu D, Perahia D, Fetters L, Nature, 370, 634 (1994).

4) Raviv U, Laurat P, Klein J, Nature, 413, 51 (2001).

5) Klein J, Raviv U, Perkin S, Kampf N, Chai L, Giasson S, J Phys Cond Mat, 16, S5437 (2005).

6) Raviv U, Giasson S, Kamph N, Gohy J-F, Jérôme R, Klein J, Nature, 425, 163 (2003).

7) Raviv U, Fray K, Sak R, Laurat P, Tadmor R, Klein J, Langmuir, 18, 7482 (2002).

8) Advincula RC, Brittain WJ, Caster KC, Rühe J Eds, "Polymer Brushes", Wiley-VCH, Weinheim (2004).

9) Yamamoto S, Ejaz M, Ohno K, Tsujii Y, Matsumoto M, Fukuda T, Macromolecules, 33, 5602 (2000).

10) Ejaz M, Yamamoto S, Ohno K, Tsujii Y, Fukuda T, Macromolecules, 31, 5934 (1998).

11) Yamamoto S, Ejaz M, Ohno K, Tsujii Y, Matsumoto M, Fukuda T, Macromolecules, 33, 5608 (2000).

12) Tsujii Y, Okayasu K, Ohno K, Fukuda T, Polym Prepr (Am Chem Soc, Div Polym Chem) 46(2), 85 (2005).

13) Sakata H, Kobayashi M, Otsuka H, Takahara A, Polym J, 37, 767 (2005)

14) Lee S, Müller M, Ratoi-Salagean M, Vörös J, Pasche S, De Paul SM, Spikes HA, Textor M, Spencer ND, Tribology Lett, 15, 231 (2003).

15) Müller M, Lee S, Spikes HA, Spencer ND, Tribology Lett, 15, 395 (2003).
16) Ohsedo Y, Takashina R, Gong JP, Osada Y, Langmuir, 20, 6549 (2003).

17) Uyama Y, Tadokoro T, Ikeda Y, J Appl Polym Sci, 39, 489 (1990).

18) Ikeuchi K, Takii T, Norikane H, Tomita N, Ohosui T, Uyama Y, Ikeda Y, Wear, 161, 179 (1993).

19) Uyama Y, Tadokoro H, Ikeda Y, Biomaterials, 12, 71 (1991).

20) Ishihara K, Ueda T, Nakabayashi N, Polym J, 22, 355 (1990).

21) Iwasaki Y, Ishihara K, Anal Bioanal Chem, 381, 534 (2005).

22) Moro $T$, Takatori $Y$, Ishihara K, Konno T, Takigawa $Y$, Matsushita T, Chung U, Nakamura K, Kawaguchi H, Nat Mater, 2, 829 (2004).

23) Kobayashi M, Takahara A, Chem Lett, 34, 1582 (2005).

24) Ishihara K, Ueda T, Nakabayashi N, Polym J, 22, 355 (1990).

25) Armarego WLF, Perrin DD Eds, "Purification of Laboratory reagents 4th Ed', Oxford, Elsevier Science (1996).

26) Kobayashi M, Terayama Y, Hosaka N, Yamada N, Torikai N, Kaido M, Suzuki A, Ishihara K, Takahara A, Soft Mat, 3, 740 (2007).

27) Terayama Y, Kobayashi M, Takahara A, Chem Lett, 36, 1280 (2007).

28) Ishida H, Koga T, Morita M, Otsuka H, Takahara A, Tribology Lett, 19, 3 (2005).

29) Iovu MC, Matyjaszewski K, Macromolecules, 36, 9346 (2003).

30) Owens DK, Wendt RC, J Appl Polym Sci, 13, 1741 (1969).

31) Kitano H, Imai M, Mori T, Gemmei-Ide M, Yokoyama Y, Ishihara K, Langmuir, 19, 10260 (2003).

32) Kiritoshi Y, Ishihara K, J. Biomater Sci Polym Ed, 13, 214 (2002).

33) Matsuda Y, Kobayashi M, Annaka M, Ishihara K, Takahara A, Polym J, 40, in press. (2008). 